\title{
PENGGUNAAN MEDIA LAGU ANAK DALAM MENINGKATKAN HASIL PEMBELAJARAN MENULIS PUISI
}

\author{
Sri Wulan Anggraeni \\ PGSD FKIP UBP Karawang \\ wulan.anggraeni@ubpkarawang.ac.id
}

\begin{abstract}
The use of media is very effective songs in the process of learning to write poetry. Songs can be used to create a comfortable atmosphere and to provide suggestions that stimulate the development of the imagination of students. This research was done in the fifth grade because of student skills in writing poetry is still low. Teachers are less stimulated and less captured the imagination of students so that learning to write poetry is considered difficult and less desirable students. The method used in this research is a classroom action research. The results showed that learning to write poetry using the medium of children's songs can increase the ability of students in grade $V$ in writing poetry. Proven with activity and learning outcomes of students to write poems on the initial conditions pre-cycle with an average value of 53.67. After the action by using the media track children has risen in the first cycle with the average value of 59 and the average value of the second cycle of 70.17. Learning showed positive changes after using the media rhymes, students are more interested and enthusiastic in learning to write poetry so as to improve learning outcomes writing poetry.
\end{abstract}

Keywords: media rhymes, and learning to write poetry

\begin{abstract}
Abstrak: Penggunaan media lagu sangat efektif dalam proses pembelajaran menulis puisi. Lagu dapat digunakan untuk menciptakan suasana yang nyaman dan memberikan sugesti yang merangsang berkembangnya imajinasi siswa. Penelitian ini dilakukan di kelas V karena keterampilan siswa dalam menulis puisi masih rendah. Guru kurang menstimulus dan kurang memberikan imajinasi siswa sehingga pembelajaran menulis puisi dianggap sulit dan kurang diminati siswa. Metode yang digunakan dalam penelitian ini adalah Penelitian Tindakan Kelas. Hasil penelitian menunjukkan bahwa pembelajaran menulis puisi dengan menggunakan media lagu anak dapat meningkatkan kemampuan siswa kelas $\mathrm{V}$ dalam menulis puisi. Terbukti dengan aktivitas dan hasil belajar menulis puisi siswa pada kondisi awal pra siklus dengan nilai rata-rata 53,67. Setelah dilakukan tindakan dengan menggunakan media lagu anak mengalami peningkatan yaitu pada siklus pertama dengan nilai rata-rata 59 dan nilai rata-rata siklus kedua 70,17. Pembelajaran menunjukkan perubahan yang positif setelah menggunakan media lagu anak, siswa lebih tertarik dan antusias dalam proses pembelajaran menulis puisi sehingga dapat meningkatkan hasil belajar menulis puisi.
\end{abstract}

\section{Kata kunci : media lagu anak, dan hasil pembelajaran menulis puisi}




\section{PENDAHULUAN}

Bahasa Indonesia mempunyai kedudukan yang sangat penting dalam kehidupan bangsa dan negara, Indonesia. Pentingnya peranan bahasa itu bersumber pada kedudukan bahasa, Indonesia sebagai bahasa nasional dan sebagai bahasa resmi Negara. Hal ini mempunyai fungsi sebagai alat untuk menjalankan admistrasi Negara, sebagai alat pemersatu berbagai masyarakat yang berbeda-beda latar belakang sosial budaya dan bahasanya, dan media untuk mengkomunikasikan kebudayaan nasional.

Mata pelajaran Bahasa Indonesia diberikan di semua jenjang pendidikan formal. Dengan demikian diperlukan standar kompetensi mata pelajaran Bahasa Indonesia yang memadai dan efektif sebagai alat berkomunikasi, berinteraksi sosial, media pengembangan ilmu dan alat pemersatu bangsa. Menurut Tariga H.G (Rosmayanti, 2010: 22) terdapat empat keterampilan berbahasa, yaitu: a) mendengarkan (menyimak), b) berbicara, c) membaca, d) menulis. Dilihat dari empat keterampilan berbahasa tersebut, salah satu keterampilan yang dimiliki oleh peserta didik yaitu keterampilan menulis, dengan menulis peserta didik dapat mengapresiasikan pikirannya dalam bentuk puisi.

Nurgiyantoro (Rosmayanti, 2010: 25) Puisi adalah genre sastra yang amat memperhatikan pemilihan aspek kebahasaan sehingga tidak salah jika dikatakan bahwa bahasa puisi adalah bahasa yang tersaring penggunaannya. Pendapat ini sejalan dengan pendapat Perrine (Siswantoro, 2008: 23) yang menyatakan bahwa puisi sebagai sejenis bahasa yang mengatakan lebih banyak dan lebih intensif daripada apa yang dikatakan oleh bahasa harian.

Masalah menulis puisi menurut Rosmayanti (2010: 2) yaitu rendahnya kreativitas siswa dalam menulis puisi dipengaruhi oleh beberapa faktor, yaitu: (a) pengalaman siswa dalam membuat puisi kurang, (b) kesulitan siswa dalam menuangkan gagasan atau ide. Hal ini disebabkan karena tidak didukungnya oleh fasilitas yang mampu mendorong daya imajinasi dan kreativitas mereka, (c) media dan metode yang digunakan oleh guru 
tidak inovatif dan variatif, sehingga pembelajaran menulis puisi tidak menarik.

Berdasarkan hasil observasi yang dilaksanakan pada tanggal 09 april 2015 di SDN. Muktiwari 02 yang dilakukan terhadap beberapa siswa, menulis puisi merupakan pembelajaran yang kurang diminati. Penyebabnya adalah terbatasnya kosa kata yang dimiliki siswa sehingga mereka sulit merangkai kata dalam bentuk puisi. Selain itu, proses pembelajaran puisi masih menggunakan metode ceramah dan latihan. Serta penyampaian materi yang masih mengandalkan buku paket sehingga pembelajaran puisi sangat membosankan.

Di lihat dari permasalahan di atas, pembelajaran menulis puisi akan lebih baik lagi jika disajikan dengan menggunakan media pembelajaran yang menarik, yang menggetarkan perasaan, mampu mewadahi kreativitas perserta didik, dan mudah dipahami siswa. Media lagu dalam menulis puisi dipilih dalam penelitian ini karena digunakan sebagai pencipta suasana sugesti, stimulus, dan sekaligus menjadi jembatan bagi siswa untuk membayangkan atau menciptakan gambaran dan kejadian berdasarkan tema lagu. Menurut Mahmud (Rosmayanti, 2010: 12) Lagu dapat menstimulus daya imajinasi dan kreativitas berfikir siswa pada saat proses menulis.

Media lagu dalam penelitian ini menggunakan lagu anak. Lagu anak dipilih karena memiliki bahasa yang sederhana dan memiliki tempo yang dinamis sehingga cocok digunakan pada siswa sekolah dasar. Hal ini sejalan dengan Rasyid, F (2010: 111) yang menyatakan bahwa lagu anak memiliki syair yang pendek, sederhana, iramanya asyik, dan bisa diikuti anak. Apalagi maknanya, sungguh dalam dan baik untuk didengar, dipahami, dan diserap anak. Lagu anak bercerita tentang dunia anak yang meliputi pengalaman anak, emosional anak, keinginan anak, dan khayalan anak yang dianggap mustahil sehingga dapat membantu mengembangkan imajinasi anak serta menggunakan syair dan bahasa sederhana sehingga pesan yang terkandung dalam lagu anak mudah diserap oleh anak. 


\section{METODE PENELITIAN}

Jenis penelitian yang digunakan dalam penelitian ini adalah penelitian tindakan kelas (classroom action research). Penelitian tindakan kelas ini dilakukan agar dapat terjadi perbaikan dan peningkatan hasil belajar siswa baik dari proses maupun hasil pembelajaran. Dalam penelitian ini terdapat variabel bebas (variable predictor) yaitu media lagu anak $\left(\mathrm{X}_{1}\right)$, dan variabel terikat (variable criteria) yaitu hasil pembeajaran menulis puisi (Y).

Metode penelitian tindakan kelas ini bersifat penerapan dan perbaikan pembelajaran menulis puisi dengan menggunakan media lagu anak. Karena sifatnya perbaikan, tentu saja pelaksanaan pembelajarannya tidak hanya cukup satu kali, melainkan diperlukan berulang-ulang dari siklus yang satu ke siklus berikutnya, sehingga hasil pembelajaran dapat optimal.

Dalam praktiknya Penelitian Tindakan Kelas (PTK) dilaksanakan melalui proses pengkajian berdaur, yang terdiri dari empat tahap, yaitu merencanakan, melakukan tindakan, mengamati, dan melakukan refleksi.
Untuk merencanakan empat tahapan tersebut, yang perlu dilakukan terlebih dahulu adalah identifikasi masalah yaitu masalah yang terjadi di dalam kelas seperti pengelolaan pembelajaran yang dilakukan guru yang berdampak bagi proses dan hasil belajar siswa dalam menulis puisi. Setelah masalah teridentifikasi, dilakukan analisis dengan mengumpulkan data yang terkait dengan masalah tersebut sehingga dapat merumuskan masalah dengan jelas.

Perencanaan yaitu proses penyusunan rencana tindakan yang akan dilakukan untuk memecahkan masalah yang ditemukan. Perencanaan harus dibuat oleh peneliti agar kegiatan yang akan dilakukan terarah dan sistematik.

Tindakan merupakan proses pelaksanaan yang dilakukan peneliti sesuai dengan rancangan yang telah dibuat sebelumnya, sebagai upaya perbaikan dalam proses pembelajaran menulis puisi dalam mata pelajaran Bahasa Indonesia, agar proses pembelajaran lebih menarik, proses pembelajaran lebih kondusif, siswa 
lebih termotivasi, dan hasil belajar siswa meningkat.

Observasi yaitu peneliti mengamati proses, hasil ataupun dampak dari pengembangan tindakan sebelumnya, baik terhadap siswa dan kinerja guru dalam proses pembelajaran, dan juga suasana kelas secara keseluruhan. Kegiatan observasi ini dilakukan selama pelaksanaan aktivitas siswa dalam belajar dan keterampilan guru dalam mengajar dengan menggunakan lembar observasi yang sudah disiapkan. Hasil observasi yang telah diamati selanjutnya digunakan untuk menata kembali langkah-langkah refleksi dan revisi pada perencanaan tindakan selanjutnya.

Refleksi yaitu tindakan mengkaji dari hasil observasi kemudian dianaisis dan dievaluasi atas informasi yang diperoleh, apakah kegiatan pembelajaran yang dilakukan dapat meningkatkan hasil belajar siswa dengan menggunakan media lagu anak. Hasil analisis dan evaluasi dijadikan acuan untuk merencanakan tindakan siklus selanjutnya.

Di bawah ini gambar perbaikan pembelajaran yang dimulai dari perencanaan, pelaksanaan, observasi, dan refleksi.

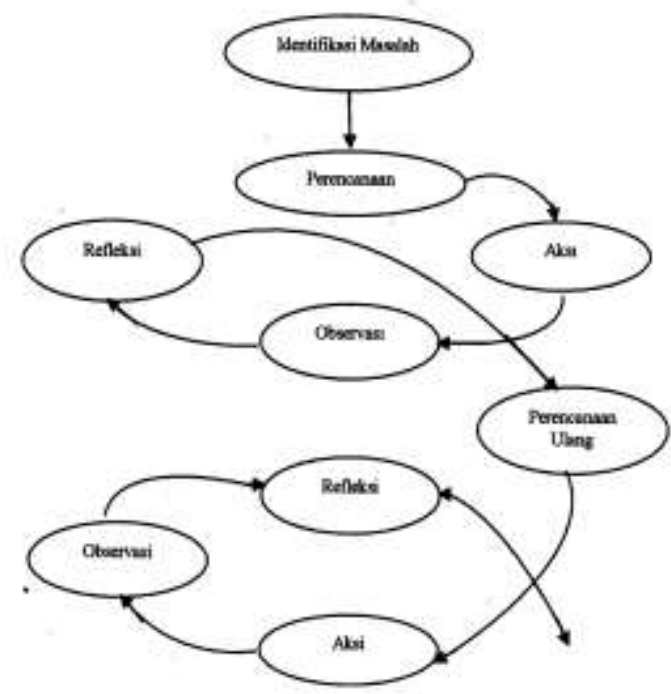

Gambar 1

Alur Penelitian Tindakan Kelas Menurut Taggart (Kasbolah, 1998: 15) 
Dari konsep PTK di atas, dapat diimplementasikan ke dalam langkah-langkah pembelajaran sebagai berikut:

1. Tahap Perencanaan.

Pada tahap awal diperlukan proses perencanaan agar kegiatan yang akan dilaksanakan dapat berjalan dengan baik dan sistematis. Tahap perencanaan dalam pembelajaran menulis puisi ada tiga kegiatan pra pembelajaran dilakukan. Pertama, penelaahan materi pembelajaran. Kedua, pemilihan lagu sebagai media pembelajaran. Ketiga, penyusunan ancangan pembelajaran.

\section{Tahap pelaksanaan.}

Pada tahap ini dilakukan tindakan yang mengacu pada tahap pertama, proses pembelajaran menulis puisi dengan menggunakan media lagu anak dibagi menjadi lima langkah. Berikut ini penjabaran mengenai lima langkah tersebut.
a) Penyampaian tujuan pembelajaran.

Pada kegiatan ini, guru memberitahukan kepada siswa mengenai tujuan pembelajaran yang akan dijalaninya. Dengan mengetahui tujuan pembelajaran yang akan dilaksanakan, diharapkan siswa lebih siap dalam mengikuti proses pembelajaran.

b) Apersepsi.

Pada tahap ini guru menjelaskan hubungan antara materi yang telah diajarkan dengan materi yang akan diajarkan. Guru memberi ulasan singkat tentang materi pembelajaran pusi.

c) Praktik Pembelajaran

Dalam praktik pembelajaran, guru menjelaskan materi puisi mengenai judul, diksi, bahasa figuratif, dan imaji.

d) Pembelajaran dengan Media Lagu.

Pada tahap ini, guru menjelaskan kepada siswa mengenai kegiatan yang akan mereka jalani dalam proses pembelajaran. Kegiatan tersebut adalah a) pemutaran lagu, b) mengimajinasikan lagu, c) penulisan gagasan yang muncul saat menikmati lagu dan sesudahnya, d) menemukan kata yang tepat yang akan dituangkan dalam bentuk puisi.

e) Menulis Puisi.

Setelah siswa menemukan gagasan berdasarkan tema lagu yang disimak, langkah berikutnya adalah 
siswa membuat puisi berdasarkan tema lagu.

3. Tahap Evaluasi.

Dalam tahap ini, guru melihat keberhasilan dan kekurangan yang terjadi selama proses pembelajaran berlangsung. Dengan melihat proses pembelajaran dan hasil belajar siswa, guru dapat menganalisis dan merefleksi dari kegiatan yang telah dilakukan. Apabila hasil pembelajaran menulis puisi masih jauh yang diharapkan maka perlu dilakukan revisi media lagu.

Penelitian tindakan kelas ini dilakukan di kelas V SDN. Muktiwari 02 Cibitung-Bekasi Tahun Pelajaran 2015/2016. Subjek penelitian ini adalah siswa kelas $\mathrm{V}$ yang berjumlah 53 siswa.

Instrumen penelitian yang digunakan untuk mengumpulkan data dalam penelitian ini adalah (1) tes hasil belajar digunakan untuk mengetahui peningkatan hasil belajar siswa mengenai informasi tentang kemampuan-kemampuan yang

\section{HASIL PENELITIAN DAN}

\section{PEMBAHASAN}

berhubungan dengan hasil belajar menulis puisi dengan menggunakan media lagu anak. (2) observasi merupakan salah satu teknik pengumpulan data yang sangat menentukan dalam pelaksanaan penelitian tindakan kelas. Lembar observasi digunakan untuk menganalisis dan merefleksi setiap siklus untuk perbaikan siklus berikutnya. Hal yang direfleksikan yaitu proses pembelajaran aktivitas guru dan siswa.

Analisis data dalam penelitian ini menggunakan analisis kualitatif, di mana analisis dilakukan secara terus menerus dari awal sampai akhir pelaksanaan penelitian. Analisis kualitatif untuk memberikan interprestasi secara konseptual terhadap kinerja guru, yang berupa kemampuan guru dalam menerapkan pembelajaran menulis puisi dengan menggunakan media lagu anak, aktivitas peserta didik, serta pola interaksi dalam proses pembelajaran. 
Tabel 1

Pencapaian Keberhasilan Tindakan (Aktivitas Guru)

\begin{tabular}{|c|c|c|c|}
\hline No. & Tindakan & Rata-rata & Ket \\
\hline 1 & Pra Siklus & 2,75 & Cukup \\
\hline 2 & Siklus I & 3,13 & Baik \\
\hline 3 & Siklus II & 3,38 & Baik \\
\hline
\end{tabular}

Secara keseluruhan aktivitas yang guru lakukan selama proses pembelajaran pada setiap siklus dapat dikategorikan baik. Terbukti dengan adanya perbaikan-perbaikan dalam semua aspek penilaian pada lembar observasi aktivitas guru. Penggunaan media lagu anak dalam pembelajaran menulis puisi di kelas V SDN.
Muktiwari 02 Kecamatan Cibitung Kabupaten Bekasi membuktikan bahwa penggunaan media lagu anak dapat meningkatan kualitas pembelajaran menulis puisi, yaitu peningkatan pencapaian hasil belajar siswa dan dapat menciptakan susana nyaman dan kondusif selama pembelajaran berlangsung.

\section{Tabel 2}

Pencapaan Keberhasilan Tindakan (Aktivitas peserta didik)

\begin{tabular}{|c|c|c|}
\hline No. & Tindakan & Persen \\
\hline 1 & Pra Siklus & $52 \%$ \\
\hline 2 & Siklus I & $80 \%$ \\
\hline 3 & Siklus II & $88 \%$ \\
\hline
\end{tabular}

Pencapaian Keberhasilan

Tindakan (Aktivitas peserta didik) siklus I dan siklus II adalah sebagai berikut: pra siklus 52\%, siklus I mencapai $80 \%$, dan siklus II mencapai $88 \%$. Hasil belajar siswa pada pembelajaran Bahasa Indonesia khususnya menulis puisi dengan menggunakan media lagu anak terbukti sangat efektif dalam menunjang keberhasilan siswa di sekolah. Dari sebelum tindakan pertama hingga tindakan kedua menunjukkan peningkatan.

Dengan menggunakan media lagu dalam pembelajaran menulis puisi dapat merangsang daya imajinasi siswa dan memudahkan siswa dalam menemukan diksi dan 
bahasa figuratif yang sesuai dengan tema lagu sehingga bahasa puisi yang

dibuat lebih bervariasi.

Tabel 2

Rekapitulasi Nilai Rata-rata Tes Per Siklus

\begin{tabular}{|l|c|}
\hline \multicolumn{1}{|c|}{ Siklus } & Nilai Rata-rata \\
\hline Pra Siklus & 53,67 \\
\hline Siklus Pertama & 59 \\
\hline Siklus Kedua & 70,17 \\
\hline
\end{tabular}

Berdasarkan data di atas, menunjukan nilai rata-rata tes siswa mulai dari pra siklus sampai dengan siklus kedua mengalami peningkatan. Nilai rata-rata pra siklus sebesar 53,67, siklus pertama sebesar 59, dan siklus kedua sebesar 70,17. Ini membuktikan bahwa dengan penggunaan media lagu anak telah menghasilkan peningkatan kualitas guru dalam proses pembelajaran menulis puisi, dan hasil belajar siswa di sekolah.

\section{PENUTUP}

Penelitian tentang Penggunaan Media Lagu Anak dalam Meningkatkan Hasil pembelajaran menulis puisi (Penelitian Tidakan Kelas yang dilakukan pada kelas V
Sekolah Dasar Negeri Muktiwari 02) dapat disimpulkan sebagai berikut:

1. Sebelum menggunakan media lagu anak dalam pembelajaran menulis puisi di SDN. Muktiwari 02 hasil belajar siswa yang diperoleh sangat rendah. Ini didasarkan kepada hasil evaluasi pra siklus dengan rata-rata kelas hanya sebesar 53,67. Siswa kurang mendapat stimulus yang baik selama pembelajaran menulis puisi. Guru tidak menggunakan media pembelajaran dan hanya menggunakan metode ceramah, sehingga tidak adanya interaksi antara guru dan siswa.

2. Selama proses pembelajaran dengan menggunakan media lagu anak lebih menunjukan suasana pembelajaran yang kondusif. Ini 
terlihat pada aktivitas siswa yang bersungguh-sungguh dalam mengimajinasikan dari lagu yang disimaknya. Siswa terlihat senang dan antusias dalam mengikuti dinamik lagu sehingga membuat siswa merasa nyaman dan luwes selama proses pembelajaran berlangsung.

3. Setelah menggunakan media lagu anak, hasil belajar telah menunjukan peningkatan dalam pembelajarn dengan hasil ratarata tes mulai tindakan pertama sebesar 59, dan tindakan kedua sebesar 70,17 dikarenakan guru telah mampu menggunakan media, dan metode yang digunakan terlaksana dengan baik.

\section{DAFTAR PUSTAKA}

Ampera, T. (2010). Pengajaran Sastra. Bandung: Widya Padjadjaran.

Anitah, S.W, dkk. (2009). Strategi Pembelajaran di SD. Jakarta: Universitas Terbuka.

Arikunto, S. (2006). Prosedur Penelitian Suatu Pendekatan Praktik. Jakarta: Rineka Cipta.

Burhanuddin, TR. (2009). Pendekatan, Metode, dan Teknik Penelitian Pendidikan.
Purwakarta: Program Pendidikan Guru Sekolah Dasar Universitas Pendidikan Indonesia.

Hartati, T. (2010). Kurikulum dan Pembelajaran Bahasa Indonesia di SD Kelas Rendah. [Online]. Tersedia: http: / /file.upi.edu. [ 5 Desember 2010]

Hermawan, R, dkk. (2007). Metode Penelitian Pendidikan SD. Bandung: UPI Press

Kasbolah, K.E.S. (1998). Penelitian Tindakan Kelas. Jakarta: Depdikbud.

Madya, S. (2007). Teori dan praktek penelitian tindakan (action research). Bandung: alfabeta.

Moleong. L. J. 2010. Metodelogi penelitian kualitatif. Bandung: remaja rosda karya.

Nova, S. (2011). Agar Menulis Seenteng Bicara. Yogyakarta: Lukita.

Pusat Pembinaan dan Pengembangan Bahasa Departemen Pendidikan dan Kebudayaan. (1989). Politik Bahasa Nasional. Jakarta: Balai Pustaka.

Rasyid, F. (2010). Cerdaskan Anakmu Dengan Musik. Yogyakarta: Diva Press.

Redaksi Shira Media. (2010). Pantun, Puisi, dan Majas. Yogyakarta: Shira Media.

Resmini, N dan Juanda, D. 2007. Pendidikan Bahasa dan Sastra di Kelas Tinggi. Bandung: UPI PRESS.

Rohani, A. (1997). Media Instruksional Edukatif. Jakarta: PT. Rineka Cipta. 
Rosmayanti, E. (2010). Pengaruh Lagu Anak- Anak Terhadap Kreativitas Menulis Puisi Siswa sekolah Dasar. Skripsi pada Jurusan Pendidikan Guru Sekolah Dasar. Bandung: Tidak diterbitkan.

Sadikin, M. (2010). Kumpulan Sastra Indonesia Pantun, Puisi, Majas, Pribahasa, Kata Mutiara. Jakarta: Gudang Ilmu.

Sanaky, H. (2011). Media Pembelajaran. Yogyakarta: Kaukaba Dipantara.

Siswantoro. (2010). Metode Penelitian Sastra. Yogyakarta: Pustaka Pelajar.

Sudjana, N. (2005). Tuntunan Penyusunan Karya Ilmiah (Makalah-Skripsi-Tesis-

Disertasi). Bandung: Sinar Baru Algensindo.

Sudjana, N dan Rivai, A. (2010). Media Pengajaran. Bandung: Sinar Baru Algensindo.

Sufanti, M. (2010). Strategi Pengajaran dan Sastra Indonesia. Surakarta: Yuma Pustaka.

Sugiono. (2009). Metode Penelitian Pendidikan Pendekatan Kuantitatif, Kualitatif dan $R \& D$. Bandung: Alfabeta

Sukma, Elvia. (2007). Peningkatan Kemampuan Menulis Puisi Siswa Kelas V SD Negeri Sumber Sari III Malang dengan Strategi Pemetaan Pikiran. [Online]. Tersedia: http: / /eprits.uny.ac.id. [5 Desember 2010]

Supardi, S. (2010). Gaya Mengajar yang Menyenangkan Siswa.
Yogyakarta: Pinus Book Publisher.

Suparno dan Yunus, M. (2009). Keterampilan Dasar Menulis. Jakarta: Universitas Terbuka.

Susilo. (2007). Panduan Penelitian Tindakan Kelas. Yogyakarta: Pustaka Book Publisher.

Tarigan, H.G. (2008). Menulis Sebagai Suatu Keterampilan Berbahasa. Bandung: Angkasa.

Trimantara, Petrus. (2005). Metode Sugesti-Imajinasi dalam Pembelajaran Menulis dengan Media Lagu. [Online]. Tersedia: http: / / www. Bpkpenabur.or.id. [5 Desember 2010]

Toha, R dan Sarumpaet. (2010). Pedoman Penelitian Sastra Anak. Jakarta: Buku Obor.

Undang-undang Republik Indonesia Nomor 20 Tahun 2003. Tentang Sistem Pendidikan Nasional. Jakarta: BP. Panca Usaha.

Wardhani, I dan wihardit, K. (2008). Penelitian tindakan kelas. Jakarta: Universitas Terbuka.

Wibowo, Trisantiyo, H. (2010). Peningkatan Kemampuan Menulis Puisi dengan Media Lagu pada Siswa Kelas V SD. Skrpsi pada Jurusan Pendidikan Bahasa dan Sastra Indonesia dan Daerah. Surakarta: Tidak diterbitkan.

Widjojoko, dan Hidayat, E. (2006). Teori Sejarah dan Sastra Indonesia. Bandung: UPI PRESS.

Yudha, A. (2010). Kenapa Guru Harus Kreatif. Bandung: PT. Mizan Pustaka. 
